Сачко О.В., кандидат юридичних наук, доцент кафьедри адміністративного і кримінального права Дніпровського національного університету ілені Олеся Гончара

\title{
ПОВІДОМЛЕННЯ ПРО ПІДОЗРУ ОСОБАМ, ЯКІ КОРИСТУЮТЬСЯ СТАТУСОМ НЕДОТОРКАННОСТІ ТА ПІДВИЩЕНИМ СТУПЕНЕМ ЗАХИСТУ
}

\begin{abstract}
Анотація. У статті аналізуються проблеми забезпечення верховенства права у разі повідомлення про підозру та здійснення особливого порядку кримінального провадження щодо осіб зі статусом недоторканності, членів рахункової палати, адвокатів та інших посадових осіб, щодо яких передбачений підвищений ступінь захисту. Розкриті пропозиції щодо удосконалення особливих порядків кримінального провадження.
\end{abstract}

Ключові слова: повідомлення про підозру, верховенство права, процесуальна форма, особливі порядки провадження.

Постановка пробллеми. Інститут повідомлення про підозру народним депутатам та іншим особам, які користуються імунітетом чи підвищеним ступенем захисту, потребує чіткої юридичної визначеності, яка відповідала 6 засадам правової держави та завданням забезпечення справедливого правосуддя.

Актуальність теми дослідження зумовлюється тим, що практика реалізації приписів правових норм щодо особливих форм, режимів і порядків провадження показує наявність недосконалості законодавства та недоліків у діяльності слідчих органів, прокуратури та суду.

Аналіз останніх наукових досліджень і публікацій, в яких започатковано розв'язання цієї проблеми, показує на певну увагу дослідників як до проблем інституту повідомлення про підозру, так і до питань удосконалення процесуальної форми кримінального провадження щодо осіб зі статусом недоторканності, адвокатів та інших посадових осіб, щодо яких передбачений підвищений ступінь захисту [1-18]. Проте наявні публікації не вичерпують всю складну проблему, а швидше утворюють фундаментальну базу для іï подальшого дослідження.

Метою цієї роботи $€$ визначення ймовірних шляхів підвищення ефективності застосування інституту повідомлення про підозру у разі задіяння особливих режимів кримінальних проваджень.

Виклад основного матеріалу дослідження. Повідомлення про підозру є багатоаспектним інститутом кримінально-процесуального права, який передбачає: 1) винесення і юридичне оформлення рішення про повідомлення про підозру; 2) вручення повідомлення про підозру; 3) роз'яснення підозрюваному його прав; 4) забезпечення підозрюваному права користуватись юридичною допомогою захисника; 5) допит підозрюваного [11, c. 551].

Письмове повідомлення про підозру відповідно до приписів статті 481 КПК України (на території фактично підконтрольній Україні) здійснюється:

1) адвокату, депутату місцевої ради, сільському, селищному, міському голові - Генеральним прокурором, його заступни- ком, прокурором області або міста Києва в межах його повноважень;

2) народному депутату України, кандидату у Президенти України, Уповноваженому Верховної Ради України з прав людини, Голові або іншому члену Рахункової палати, прокурору Спеціалізованої антикорупційної прокуратури, Директору або іншому працівнику Національного антикорупційного бюро України, заступникам Генерального прокурора України, члену Національного агентства 3 питань запобігання корупції - Генеральним прокурором (виконувачем обов'язків Генерального прокурора);

3) судді, судді Конституційного Суду України, присяжному на час виконання ним обов'язків у суді, Голові, заступнику Голови, члену Вищої ради правосуддя, Голові, заступнику Голови, члену Вищої кваліфікаційної комісії суддів України, працівникам Національного антикорупційного бюро України Генеральним прокурором або його заступником;

4) Генеральному прокурору - заступником Генерального прокурора.

Безумовно, що ця норма закону не $є$ сталою і з формуванням ДБР, Бюро фінансових розслідувань та Антикорупційного суду виникне потреба змін і доповнень до цієї норми. Але закладені тут концептуальні підходи скоріш за все в основному будуть зберігатись.

Хоча викликає певну критику занадто ускладнена за суб'єктами повноважень процедура повідомлення про підозру народним депутатам України - виключно Генеральним прокурором (або виконувачем обов'язків Генерального прокурора). Коли зважити на ситуацію з обмеженими строками повідомлень про підозру після затримання особи, а також на те, що Генеральному прокурору буде потреба в повідомленні про підозру протягом певного проміжку часу не одному і не декільком, а більш значному числу депутатів, то можна змоделювати ситуацію, коли Генеральний прокурор фізично не в змозі буде це зробити.

Приклади слідчої практики вказують на певні колізії, які витікають 3 таких «вимогливих» приписів цього закону. Так, у справі народного депутата України Надії Савченко, всупереч вимогам указаної норми, повідомлення про підозру було вручене прямо в стінах Верховної Ради України, до того ж не Генеральним прокурором, як того вимагає вищеназвана норма, а слідчим Генеральної прокуратури. 3 точки зору сторони захисту, зважаючи, що не мало місця затримання особи, можна стверджувати, що законного повідомлення про підозру не відбулось, а відтак Надія Савченко на момент розгляду в суді подання щодо їі арешту не мала статусу підозрюваного. Відтак одне порушення потягло інше - незаконний арешт. I хоча сто- 
рона захисту не скористалась повною мірою такими колізіями, не заявила цивільного позову до Генерального прокурора з приводу порушення ним презумпції невинуватості, висловлюваннями у Верховній Раді, щоб тим самим створити усі підстави для відводу Генерального прокурора від участі в справі, чим фактично можна було поставити стороні обвинувачення «мат у три ходи», проте не факт, що подібні граблі не знайдуть «своїх прихильників» у майбутньому. Думається, що прив' язувати повноваження щодо повідомлення про підозру до однієї найвищої посадової особи невиправдано і необачливо, навіть 3 огляду на те, що вона одна і може опинитись у ситуації зацікавленої в справі особи, а юридично є незамінною.

Варто погодитися iз думкою В.М. Тертишника, який вважає, що для повідомлення особі про підозру у слідчого, прокурора має бути система доказів, яка виключала б будь-які сумніви $з$ приводу того, що: 1) кримінальне правопорушення справді відбулося; 2) кримінальне правопорушення вчинене підозрюваною особою; 3) діяння підозрюваної особи містить склад конкретного злочину; 4) відсутні обставини, які виключають їі відповідальність [11, с. 549].

Разом з тим повідомлення про підозру є фактичним актом притягнення особи до відповідальності, а стосовно народного депутата закон вимагає отримання на це згоди Верховної Ради України, а сам порядок надання такої згоди визначається Законом України «Про Регламент Верховної Ради України». Відповідно до ст. 218 цього Закону подання про надання згоди на притягнення до кримінальної відповідальності, затримання чи арешт народного депутата ініціюється прокурором та вноситься на розгляд ВРУ Генеральним прокурором (виконувачем обов'язків Генерального прокурора).

Як зазначає С.В. Свириденко, постає цілком логічне питання про реальну можливість отримання достатніх доказів для одержання згоди парламенту на притягнення народного депутата до кримінальної відповідальності, з огляду на їх суттєву обмеженість щодо можливості проведення слідчих (розшукових) дій та негласних слідчих (розшукових) дій стосовно народного депутата, з якого не знято недоторканність. Крім того, не слід забувати, що подання про надання згоди на притягнення до кримінальної відповідальності народного депутата має бути вмотивованим і достатнім, містити конкретні факти і докази, що підтверджують факт вчинення зазначеною в поданні особою суспільно небезпечного діяння, визначеного КК України [7, с. 136].

Фактично створюється замкнуте коло - «для притягнення до відповідальності народного депутата має бути система доказів», яка поза розумним сумнівом підтверджує наявність в його діях складу злочинну, а для здобуття доказів із застосуванням передбачених законом заходів кримінального забезпечення «потрібна згода ВРУ на притягнення народного депутата до відповідальності».

Зокрема, ч. 3 ст. 482 КПК України зазначає: «обшук, затримання народного депутата України чи огляд його особистих речей i багажу, транспорту, жилого чи службового приміщення, а також порушення таємниці листування, телефонних розмов, телеграфної та іншої кореспонденції та застосування інших заходів, зокрема негласних слідчих дій, що відповідно до закону обмежують права і свободи народного депутата України, допускаються лише у разі, якщо Верховною Радою України надано згоду на притягнення його до кримінальної відповідальності, якщо іншими способами одержати інформацію неможливо».
Ще більш радикальні заходи захисту закон встановлює щодо Голови Рахункової палати та інших членів Рахункової палати, Так, Законом України «Про Рахункову палату» встановлюються такі правила. Голова Рахункової палати та інші члени Рахункової палати не можуть бути затримані, притягнуті до кримінальної відповідальності без згоди Верховної Ради України. Повідомлення про підозру цим особам може бути здійснено лише Генеральним прокурором України.

Проблематичність ситуації усугубляється також тим, що Генеральний прокурор може не бути учасником конкретного кримінального провадження, якщо не здійснював процесуального керівництва слідством, а відтак і наділення його повноваженнями щодо внесення подання до ВРУ та доведення його обгрунтованості викликає багато критичних зауважень.

Слід мати на увазі, зазначає С.В. Свириденко, що Генеральний прокурор (виконуючий обов'язки Генерального прокурора), його заступник та керівник регіональної прокуратури - це відповідна посадова особа, передбачена Законом України «Про прокуратуру», але не процесуальний iï статус. Таке питання виникає з огляду на те, що, не маючи жодного відношення до кримінального провадження, зокрема, не будучи процесуальним керівником або включеним до групи прокурорів, останні не уповноважені здійснювати жодних процесуальний дій. Тому вбачається цілком логічним, щоб у разі проведення досудового розслідування щодо окремої категорії осіб за потреби до складу групи прокурорів слід включати Генерального прокурора (виконуючого обов'язки Генерального прокурора), його заступника та керівника регіональної прокуратури із винесенням про це відповідної постанови [7, с. 146].

Безумовно, це може стати одним з виходів зі створеної законом «безвихідної ситуації». На наш погляд, варто відмовитись від покладання обов'язків вносити подання до ВРУ на Генерального прокурора, делегувавши ці повноваження керівникам регіональних прокуратур за принципом рівності з іншими суб'єктами процесу, названими в цій главі КПК.

Важливим доктринальним питанням розвитку процесуальної форми правосуддя є питання балансу приватних і публічних інтересів у разі встановлення певних імунітетів щодо депутатів та інших посадових осіб. Сьогоднішній статус недоторканності депутата не відповідає європейським стандартам, $є$ штучним нагромадженням бюрократичних і сумнівних з точки зору забезпечення верховенства права та досягнення мети кримінальних проваджень процедур, а відтак потребує скасування.

На наш погляд, стосовно народних депутатів, слідчих, прокурорів, детективів, суддів, адвокатів та інших фахівців права, які надають правничу допомогу, доцільно встановити єдиний універсальний імунітет - затримання, арешт, притягнення таких осіб до кримінальної відповідальності допускається за згодою Міністра юстиції, виданою на підставі подання Генерального прокурора чи його заступника, керівника регіональної прокуратури або Директора НАБУ чи його заступника (щодо працівників самої прокуратури). Народні депутати не мають затримуватись чи заарештовуватись у період сесійної роботи у Верховній Раді України.

Висновок. Більш широке запровадження в слідчу і судову практику інститутів особливих спрощених форм, порядків і режимів кримінальних проваджень потребує зміцнення гарантій захисту прав і свобод учасників процесу, розробленні та запровадженні з урахуванням принципу верховенства права 
більш досконалої процедури слідства і судового розгляду відповідних справ, виваженого застосування правил індемнітету та підвищеного ступеня захисту, без використання привілею недоторканності.

Перспективи подальшого дослідження проблеми вбачаються в розробці концептуальної моделі та окремої глави КПК України, присвяченої особливим формам кримінальних проваджень.

\section{Jimepamypa:}

1. Андрейчук А.В. Правова природа повідомлення про підозру. Прикарпатський юридичний вісник. Випуск 1 (3). 2013. С. 259-270.

2. Іващенко О.В. Правова природа повідомлення про підозру за новим Кримінальним процесуальним кодексом України. Наше право. 2012. № 4. Ч. 2. С. 89-94.

3. Колюх В. Депутатська недоторканність: зарубіжний досвід і українські проблеми. Віче. 2015. № 3.

4. Корнієнко М.В., Тертишник В.М. Концептуальні проблеми процесуального інституту негласних слідчих (розшукових) дій. Науковий вісник Ужгородського національного університету. Серія ПРАВО. Випуск 39. Том 2. 2016. С. 105-109.

5. Наливайко $€$. Проблемні питання повідомлення особі про підозру та зупинення досудового розслідування. Публічне право. 2013. № 1 (9). C. 375-380.

6. Свириденко С.В. До проблеми законодавчого врегулювання здійснення кримінального провадження щодо осіб, які користуються недоторканністю. Науковий вісник публічного та приватного права. 2017. Вип. 5. С. 207-212.

7. Свириденко С.В. Досудове розслідування у кримінальному провадженні щодо осіб, які користуються недоторканністю: дисертація на здобуття наукового ступеня кандидата юридичних наук (доктора філософії) за спеціальністю 12.00 .09 - кримінальний процес та криміналістика; судова експертиза; оперативно-розшукова діяльність. Університет державної фіскальної служби України, Ірпінь, 2018. 222 с.

8. Свириденко С.В. Особливості повідомлення про підозру особам, які користуються недоторканістю. Науковий вісник публічного та приватного права. 2017. Вип. 6. С. 151-159.

9. Татаров О. Реально ли посадить украинского депутата? Факт один - мнения разные. Закон і Бізнес. Вип. № 43 (1237). URL: http://zib.com.ua/ua/ pda/119350.html

10. Татаров О.Ю. Проведення негласних слідчих (розшукових) дій стосовно окремих категорій осіб. Науковий вісник Херсонського державного університету. Серія юридичні науки. 2015. Вип 2-3. T. 1. C. 205-208.

11. Тертишник В.М. Кримінальний процес України: підручник. 7-ме вид., доповн. і перероб. К.: Алерта, 2017. 840 с.

12. Тертишник В.М. Науково-практичний коментар Кримінального процесуального кодексу України. Вид. 15-те, доповн. і перероб. К.: Правова Єдність, 2018. 854 с.
13. Тертишник В.М. Конституційна реформа: пошук нової парадигми українського конституціоналізму. Актуальні проблеми вітчизняної юриспруденції. 2015. № 6. С. 52-59. URL: file://C:/Users/User/ Downloads/apvu_2015_6_9.pdf

14. Черкова В.Ю. Процесуальні особливості набуття особою статусу підозрюваного в кримінальному провадженні. Науковий вісник Львівського державного університету внутрішніх справ. Серія «Юридична». 2012. Вип. 4. С. 457-468.

15. Шаранич С.С. Депутатський імунітет та кримінальна відповідальність: європейський досвід. Актуальні проблеми держави і права. 2014. № 73. С. 462-467.

16. Шевчишен А.В. Деякі особливості початку досудового розслідування щодо осіб, зазначених у статті 480 КПК України, у разі вчинення ними корупційного злочину. Наше право. 2017. № 1. С. 114-121.

17. Щербак I. Види підозри за новим Кримінальним процесуальним кодексом. Підприємництво, господарство і право. 2013. № 3. С. $132-134$.

18. Юрченко Л.В. Повідомлення про підозру: новела кримінального процесуального законодавства. Актуальні проблеми публічного та приватного права: Збірник матеріалів Міжнародної науково-практичної конференції (м. Запоріжжя, 03 жовтня 2012 року). Запоріжжя: Класичний приватний університет, 2012. С. 355-357.

Сачко А. В. Уведомление о подозрении лицам, которые пользуются статусом неприкосновенности и усиленной степенью защиты

Аннотация. В статье анализируются проблемы обеспечения верховенства права при уведомлении о преступлении и применении института особенного порядка уголовного производства в отношении лиц со статусом неприкосновенности, членов счетной палаты, адвокатов и иных должностных лиц, относительно которых предусмотрен усиленный режим защиты. Раскрыты предложения по совершенствованию особенных порядков производства.

Ключевые слова: уведомление о преступлении, верховенство права, процессуальная форма, особые формы уголовного производства.

Sachko A. Messages about suspicious persons who enjoy immunity status and a high degree of protection

Summary. The article analyses problems of the rule of law when reporting suspicious and special order criminal proceedings against persons with the status of immunity, the members of the Accounting Chamber, attorneys and other officials regarding the which provided an increased level of protection. Disclosed proposals for improvement of the special orders of the criminal proceedings.

Key words: message about the suspicious, rule of law, procedural form, special order proceedings. 